\title{
Some Wild Edible Plants of Tosya District (Kastamonu, Turkey)*
}

\author{
Gamze Tuttu (Corresponding author) \\ Cankiri Karatekin University, Faculty of Forestry, \\ Department of Forest Engineering, 18200, Cankiri, Turkey \\ E-mail: gamze.tuttu@gmail.com
}

Gokhan Abay

Recep Tayyip Erdogan University, Division of Landscape Architecture, Department of Plant Materials and Propagation Techniques, Rize, Turkey

E-mail: gokhanabay@gmail.com

Sinasi Yildirimli

Hacettepe University, Faculty of Science,

Department of Biology, Beytepe, Ankara, Turkey

E-mail: otdergisi.yldrml@gmail.com

The research is financed by ÇAKU scientific research projects unit (BAP-project no: of 12035d02).

\begin{abstract}
The study was carried out between 2014-2016 to determine the ethnobotanical characteristics of the Tosya district. For this purpose, in the field studies, Tosya center and villages have been visited and plant specimens were collected and to get information about the used parts of plants. Their local names and their usage patterns were recorded. Face-to-face interviews were conducted with 200 people which are 110 female and 90 male. In addition, a survey about 'edible plants' was applied to 217 people. According to the results of the interviews and surveys, 22 natural plant taxa, the most common use as food, were determined. These are: Scorzonera laciniata subsp. laciniata, Taraxacum serotinum, Tragopogon latifolius var. angustifolius, Tragopogon longirostris var. abbreviatus, Capsella bursa-pastoris, Sinapis arvensis, Silene vulgaris var. vulgaris, Stellaria media subsp. media, Chenopodium album subsp. album var. album, Bryonia alba, Origanum sipyleum, Thymus sipyleus subsp. rosulans, Malva sylvestris, Plantago lanceolata, Plantago major subsp. major, Polygonum cognatum, Rumex acetosella, Rumex crispus, Rumex obtusifolius, Rumex scutatus, Portulaca oleracea, Urtica dioica.
\end{abstract}

Keywords: Ethnobotany, Tosya, wild edible plants, food source.

*This study was presented as a poster in "Int. Symp. on Biodiversity and Edible Wild Species (Bews 2017), 3-5 April 2017, Antalya/Turkey".

DOI: $10.7176 / \mathrm{JSTR} / 5-3-15$

\section{Tosya İlçesinin Bazı Yabani Besin Bitkileri (Kastamonu, Türkiye)}

Özet

Bu çalışma 2014-2016 yılları arasında Tosya ilçesinin etnobotanik özelliklerinin belirlenmesi amacıyla yapılan araştırmanın yenilebilen bazı doğal bitkilerini kapsamaktadır. Tosya merkez ve köylerinde yapılan arazi çalı̧̧malarında bitki örnekleri toplanarak bitkilerin kullanılan kısımları, yöresel isimleri ve kullanılış biçimleri hakkındaki bilgiler kaydedilmiştir. Çalışmada 90'ı erkek 110'u kadın olmak üzere toplam 200 kişi ile röportaj yapılmıştır. Ayrıca 217 kişiye yenen bitkiler ile ilgili anket uygulanmıştır. Röportaj ve anket sonuçlarına göre gıda olarak kullanımı en yaygın olan 22 doğal bitki taksonu tespit edilmiştir. Bunlar: Scorzonera laciniata subsp. laciniata, Taraxacum serotinum, Tragopogon latifolius var. angustifolius, Tragopogon longirostris var. 
abbreviatus, Capsella bursa-pastoris, Sinapis arvensis, Silene vulgaris var. vulgaris, Stellaria media subsp. media, Chenopodium album subsp. album var. album, Bryonia alba, Origanum sipyleum, Thymus sipyleus subsp. rosulans, Malva sylvestris, Plantago lanceolata, Plantago major subsp. major, Polygonum cognatum, Rumex acetosella, Rumex crispus, Rumex obtusifolius, Rumex scutatus, Portulaca oleracea, Urtica dioica'dir.

Anahtar Kelimeler: Etnobotanik, Tosya, Yenen bitkiler, Gıda kaynağı.

\section{Introduction}

The relationship between man and plants is as old as human history. In the course of time, humans learned to identify plants in the nature, benefit from them and developed different forms of usage. Some plants have been used as food sources and some of them in the treatment of diseases, for centuries (Y1ldirmli, 2004). In terms of plant diversity Turkey is one of the richest countries. Researchers have been carried out studies on medicinal plants for a long time. However, wild edible plants have been studied for the last 15-20 years. In the light of these surveys, it is reported that the total number of plants used as food approximately 1200 in our country (Ertuğ, 2014).

Anatolia has a rich 'herb culture'. Many wild plants are collected and used as food commonly. The informations about these edible plants in Turkey were created a cultural heritage to transferred from generation to generation. This culture must be recorded and this rich heritage must be prevented from disappearing (Baytop, 1884; Ylldirıml, 2004). In this regard, the aim of the study is to collect information about the wild edible plants usages in Tosya district before they are completely lost.

The study area is situated in Black Sea Region, at the transition region between Irano-Turanian and Euro-Siberian phytogeographical regions, in southeast of the Kastamonu province, surrounded by Kastamonu-Çankırı and Çorum provinces (Figure 1). The research area is $1195 \mathrm{~km}^{2}$, the altitude is $850 \mathrm{~m}$. Tosya district has 23 neighborhoods and 53 villages (T.C. Tosya Kaymakamlığı Brifing, 2013; tosya.bel.tr, 2017).

The research area located at a very important point in terms of transportation. The highway which is connecting the west of the country to the east and north passes through the middle of the district. This highway route was known as Silk Road. Due to the fact that it was established on the Silk Road, it has been one of the most important trade centers in Anatolia, in the past (İbret, 2003; İbret, 2013). Nowadays, Tosya is a district that stands out with its viticulture and rice production.

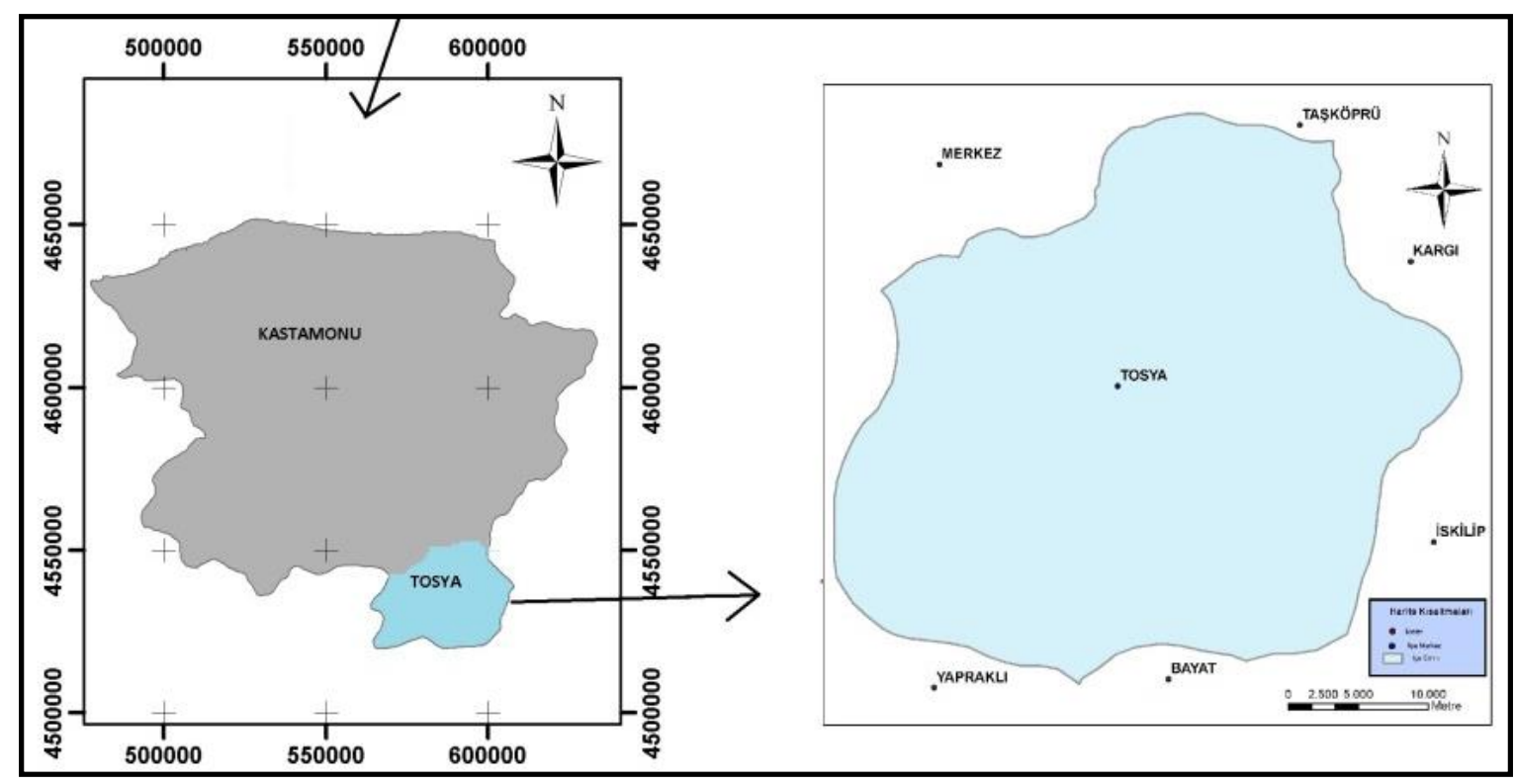

Figure 1. Geographical Location of the Research Area 


\section{Materials and Methods}

This study was carried out in Tosya center and 53 villages (including neighborhoods, uplands and the other sites), it is a part of the PhD thesis named "Flora and Ethnobotany of Tosya District (Kastamonu)" (Tuttu, 2017). The plants specimens were collected and photographed with the help of the informants, between 2014-2016. Their local names, used parts and their usage patterns have been recorded. The specimens were identified by using 'Flora of Turkey and the East Aegean Islands' (Davis 1965-1985; Davis et al. 1988; Güner et al. 2000). All specimens were pressed and dried using the standard herbarium methods.

In the field studies, face-to-face interviews were conducted with 200 people which are 110 female and 90 male. Also we went to Bazaar to get information from sellers. In addition the plants were photographed sold in the Bazaar and information about used parts of the plants were recorded. In addition, a survey about 'edible plants' was applied to 217 people, with the aid of students (Ertuğ, 2003; Figure 2).

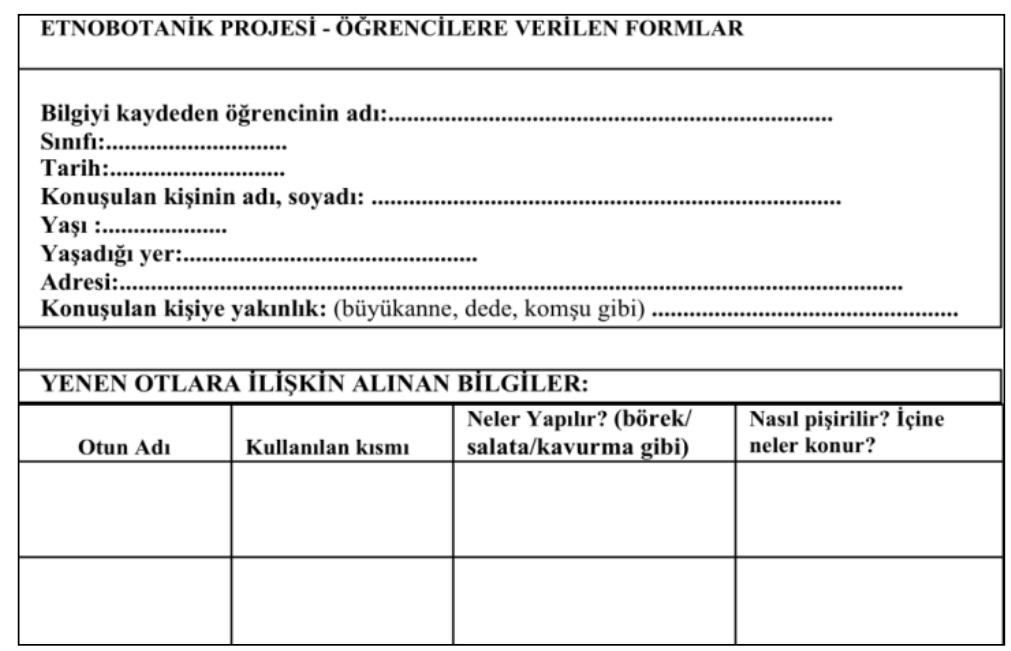

Figure 2. Survey Sample About Edible Plants

\section{Results and Discussion}

According to the results of the interviews and surveys, 22 taxa, the most common use as food, were determined. These are represented in Table 1. Photos of some plants which were taken from the study area are given in Figure 3. 


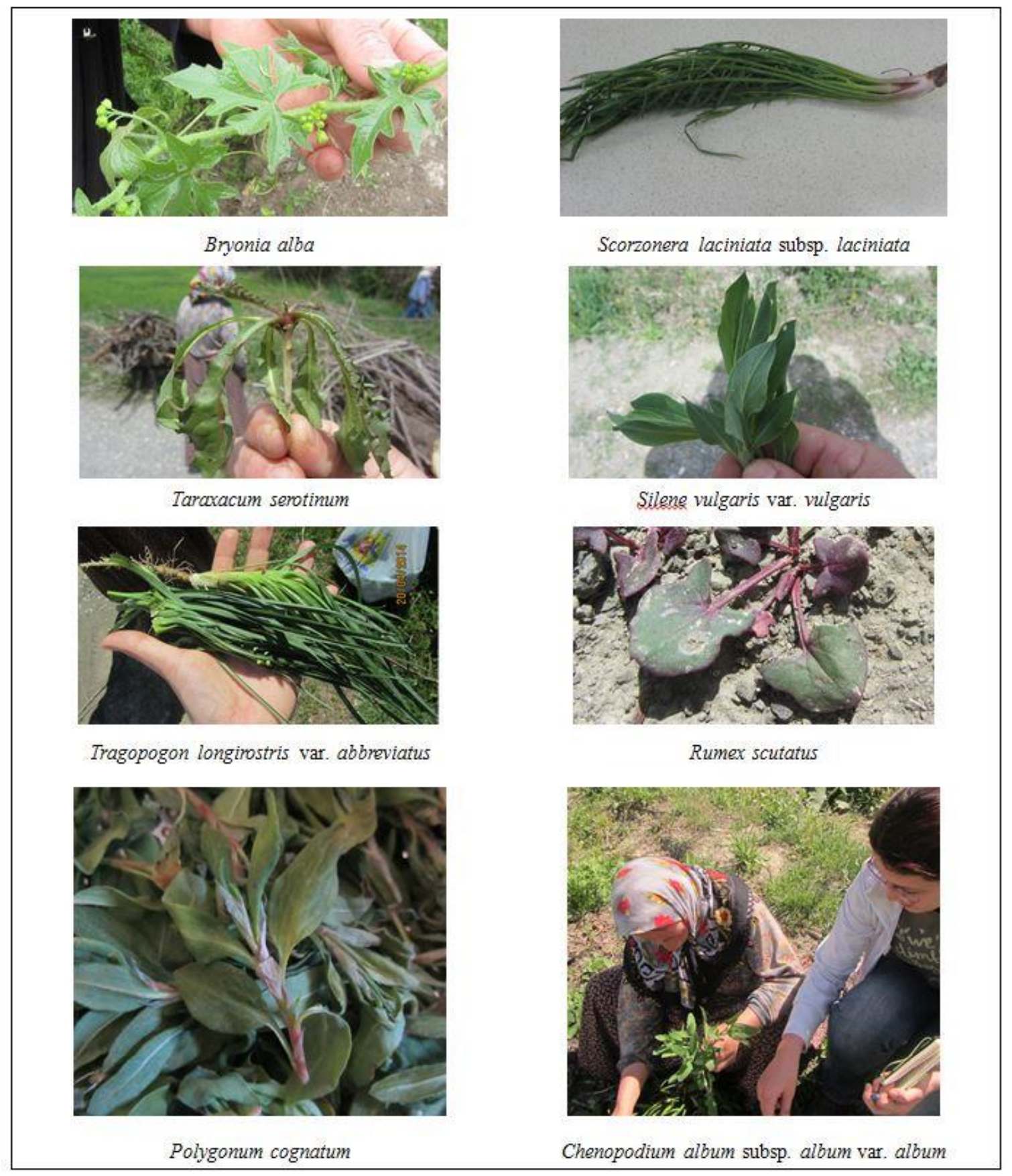

Figure 3. Some Wild Edible Plants of Tosya 
Table 1. Some wild edible plants of Tosya District

\begin{tabular}{|c|c|c|c|c|}
\hline Family & Botanical name & Local name & Used part & Usage \\
\hline Asteraceae & $\begin{array}{c}\text { Scorzonera laciniata } \mathrm{L} . \\
\text { subsp. laciniata }\end{array}$ & $\begin{array}{c}\text { Tekecen, Tekesakalı, } \\
\text { Dedesakalı }\end{array}$ & Aerial parts & Eaten (raw) \\
\hline Asteraceae & $\begin{array}{l}\text { Taraxacum serotinum } \\
\text { (Waldst. \& Kit.) Poiret }\end{array}$ & $\begin{array}{l}\text { Karakavuk, Karavuk, } \\
\text { Karagavuk, Karaok, } \\
\text { Karagoğuk, } \\
\text { Dedekovuğu }\end{array}$ & Young leaves & $\begin{array}{l}\text { Eaten (raw), eaten } \\
\text { with bread, salad }\end{array}$ \\
\hline Asteraceae & $\begin{array}{c}\text { Tragopogon latifolius } \\
\text { Boiss. var. angustifolius } \\
\text { Boiss. }\end{array}$ & $\begin{array}{l}\text { Yemlik, Yelmik, Yilmik, } \\
\text { Yermük, Yelmük }\end{array}$ & $\begin{array}{l}\text { Young aerial } \\
\text { parts }\end{array}$ & $\begin{array}{l}\text { Eaten (raw), eaten } \\
\text { with bread, salad, } \\
\text { Cooked with } \\
\text { Capsella bursa- } \\
\text { pastoris }\end{array}$ \\
\hline Asteraceae & $\begin{array}{l}\text { Tragopogon longirostris } \\
\text { Bisch. Ex. Schultz Bip } \\
\text { var. abbreviatus Boiss. }\end{array}$ & $\begin{array}{l}\text { Yemlik, Yelmik, Yilmik, } \\
\text { Yermük, Yelmük }\end{array}$ & $\begin{array}{l}\text { Young aerial } \\
\text { parts }\end{array}$ & $\begin{array}{c}\text { Eaten (raw), eaten } \\
\text { with bread, salad, } \\
\text { Cooked with } \\
\text { Capsella bursa- } \\
\text { pastoris }\end{array}$ \\
\hline Brassicaceae & $\begin{array}{l}\text { Capsella bursa-pastoris } \\
\text { (L.) Medik }\end{array}$ & $\begin{array}{l}\text { Kuş otu, Kedi ciynağı, } \\
\text { Ciynak }\end{array}$ & $\begin{array}{l}\text { Young aerial } \\
\text { parts }\end{array}$ & $\begin{array}{c}\text { Eaten (raw), salad, } \\
\text { roasted, pita filling, } \\
\text { meal }\end{array}$ \\
\hline Brassicaceae & Sinapis arvensis L. & $\begin{array}{l}\text { Zamzam, Namzam, } \\
\text { Hardal otu, Haldar otu }\end{array}$ & Young leaves & $\begin{array}{l}\text { Eaten (raw), Salad } \\
\text { (after boiled), pie }\end{array}$ \\
\hline Caryophyllaceae & $\begin{array}{c}\text { Silene vulgaris } \\
\text { (Moench) Garcke var. } \\
\text { vulgaris }\end{array}$ & $\begin{array}{l}\text { Kırşayık, Kırşavuk, } \\
\text { Kırışayık, Gıvşayık } \\
\text { mancar, Kıvşayak, } \\
\text { Kıvırşayık, Kıvşayık, } \\
\text { Kıvırşak, Kuşayak }\end{array}$ & $\begin{array}{l}\text { Young aerial } \\
\text { parts }\end{array}$ & $\begin{array}{c}\text { Meal, soup, roasted } \\
\text { then added yogurt } \\
\text { with garlic, boiled } \\
\text { then added yogurt } \\
\text { with garlic, roasted } \\
\text { with egg }\end{array}$ \\
\hline Caryophyllaceae & $\begin{array}{l}\text { Stellaria media (L.) Vill. } \\
\text { subsp. media }\end{array}$ & $\begin{array}{c}\text { Kuşgöyneği, Kazayak } \\
\text { otu, Kazayağ1, } \\
\text { Civcivboğan } \\
\end{array}$ & $\begin{array}{l}\text { Young aerial } \\
\text { parts }\end{array}$ & Eaten (raw), roasted \\
\hline Chenopodiaceae & $\begin{array}{l}\text { Chenopodium album L. } \\
\text { subsp. album var. album }\end{array}$ & $\begin{array}{l}\text { Yağlıca, Yağlı pancar, } \\
\text { Yağlı mancar, Küllük } \\
\text { otu }\end{array}$ & $\begin{array}{l}\text { Young aerial } \\
\text { parts }\end{array}$ & $\begin{array}{l}\text { Meal, pie, roasted, } \\
\text { soup, boiled then } \\
\text { added yogurt with } \\
\text { garlic, cooked with } \\
\text { rice then added } \\
\text { yogurt with garlic }\end{array}$ \\
\hline Cucurbitaceae & Bryonia alba $\mathrm{L}$. & $\begin{array}{l}\text { Ülüngür, Ürüngül, } \\
\text { Siğırkuyruğu }\end{array}$ & Young shoots & $\begin{array}{c}\text { Eaten (after boiled), } \\
\text { roasted }\end{array}$ \\
\hline Lamiaceae & Origanum sipyleum L. & Kekik, Ciğer otu & Aerial parts & Tarhana \\
\hline Lamiaceae & $\begin{array}{l}\text { Thymus sipyleus subsp. } \\
\text { rosulans (Borbás) Jalas }\end{array}$ & Kekik & Aerial parts & Spice, tea \\
\hline Malvaceae & Malva sylvestris $\mathrm{L}$. & $\begin{array}{c}\text { Ebegümeci, } \\
\text { Ebemgümeci, gömeç } \\
\text { otu }\end{array}$ & Aerial parts & $\begin{array}{l}\text { Meal, salad, pie, } \\
\text { roasted }\end{array}$ \\
\hline Malvaceae & Malva sylvestris $\mathrm{L}$. & $\begin{array}{c}\text { Ebegümeci, } \\
\text { Ebemgümeci, gömeç } \\
\text { otu }\end{array}$ & Leaves & Cooked as sarma \\
\hline
\end{tabular}


Table 1. Some wild edible plants of Tosya District (Continued)

\begin{tabular}{|c|c|c|c|c|}
\hline Family & Botanical name & Local name & Used part & Usage \\
\hline Plantaginaceae & Plantago lanceolata $\mathrm{L}$. & $\begin{array}{c}\text { Sinirli yaprak, Sinirli ot, } \\
\text { Sinir Otu }\end{array}$ & Leaves & Roasted, pie, tea \\
\hline Plantaginaceae & $\begin{array}{c}\text { Plantago major L. } \\
\text { subsp. major }\end{array}$ & $\begin{array}{c}\text { Sinirli yaprak, Sinirli ot, } \\
\text { Sinir Otu } \\
\end{array}$ & Leaves & Roasted, pie, tea \\
\hline Polygonaceae & $\begin{array}{l}\text { Polygonum cognatum } \\
\text { Meissn. }\end{array}$ & $\begin{array}{l}\text { Madımak, Maşmak, } \\
\text { Madımalak }\end{array}$ & Aerial parts & $\begin{array}{l}\text { Meal, pie, soup, } \\
\text { roasted then added } \\
\text { yogurt with garlic, } \\
\text { salad, roasted with } \\
\text { egg }\end{array}$ \\
\hline Polygonaceae & Rumex acetosella L. & Kuzu kulağı, Ekşimük & Young leaves & Eaten (raw) \\
\hline Polygonaceae & Rumex crispus L. & $\begin{array}{c}\text { Efelek, Evelek, Öfelek, } \\
\text { Mancar efeleği, } \\
\text { Kökükızıl Mancar }\end{array}$ & Leaves & $\begin{array}{l}\text { Cooked as sarma, } \\
\text { soup }\end{array}$ \\
\hline Polygonaceae & $\begin{array}{c}\text { Rumex obtusifolius L. } \\
\text { subsp. subalpinus } \\
\text { (Schur) Celak }\end{array}$ & Pancar, Mancar & Leaves & $\begin{array}{l}\text { Roasted, meal, } \\
\text { roasted with egg }\end{array}$ \\
\hline Polygonaceae & Rumex scutatus L. & $\begin{array}{l}\text { Acıgıcı, Süpürge otu, } \\
\text { Acıkulak, Acıoglak }\end{array}$ & Young leaves & Eaten (raw), meal \\
\hline Portulacaceae & Portulaca oleracea L. & Semizotu, Soğukluk otu & Aerial parts & $\begin{array}{l}\text { Eaten (raw), Soup } \\
\text { with yogurt named } \\
\text { 'Ayranliaşı', meal, } \\
\text { salad, pie, roasted } \\
\text { then added yogurt } \\
\text { with garlic } \\
\end{array}$ \\
\hline Portulacaceae & Portulaca oleracea L. & Semizotu, Soğukluk otu & Leaves & $\begin{array}{l}\text { Eaten (raw), salad, } \\
\text { cacik }\end{array}$ \\
\hline Urticaceae & Urtica dioica $\mathrm{L}$. & Isırgan Otu & Aerial parts & $\begin{array}{c}\text { Meal, Salad, pie, } \\
\text { roasted, boiled, soup, } \\
\text { tea }\end{array}$ \\
\hline
\end{tabular}

As a result of this study 22 wild edible taxa belonging to 11 families are reported. Among them, 20 taxa were found to be used as food source, one takson were found to be used as herbal tea and 2 taxa were found to be used as spice. The most common families which are used as food: Polygonaceae, Asteraceae, Brassicaceae and Caryophyllaceae are listed as. Most common used part of plants as food is the aerial parts (13 taxa) and leaves (10 taxa). However, more than one parts of some plants are used as food. Most common usage form is roasted then added yogurt with garlic, eaten (raw) and salad. Also, a lot of plants in the list, can be prepared as food in many different usage forms. For example, Malva sylvestris and Rumex crispus leaves are cooked as sarma. It's aerial parts are cooked as meals, pie or soups.

10 of these plants are eaten raw while 15 are consumed by cooking, some of them are consumed in both ways. Especially, fresh herbs which are grown in early spring time, eatan raw. On the other hand, Origanum sipyleum's aerial parts used for to make a traditional soup named 'Tarhana', it is sold in Bazaar, in the late summer. Furthermore, Scorzonera laciniata subsp. laciniata, Silene vulgaris var. vulgaris, Bryonia alba and Urtica dioica are the other wild plant species which sold in the Bazaar.

\section{References}

Baytop, T. (1984). Türkiye’de Bitkiler ile Tedavi (Geçmişte ve Bugün). Sanal Matbaacılık, İstanbul.

Davis, P. H. (1965-1985). Flora of Turkey and the East Aegean Islands, Edinburgh University Press, Volumes 1-9, Edinburgh. 
Davis P. H., Mill R. R., Tan K. (1988). Flora of Turkey and the East Aegean Islands (supplement 1), Edinburgh University Press, volume 10, Edinburgh.

Ertuğ, F. (2003). Etnobotanik Fiş Örneği ve Çerçeve Soruları, Türkiye Kültür Envanteri Kılavuzu, TÜBATÜKSEK Yayınları, s.101-110, İstanbul.

Ertuğ, F. (2014). Etnobotanik. Şu eserde: Güner, A. ve Ekim, T. (edlr.) Resimli Türkiye Floras1, cilt 1. ANG Vakfi, Flora Araştırmaları Derneği ve Türkiye İş Bankası Kültür Yay., 319-420, İstanbul.

Güner, A., Özhatay, N., Ekim, T., Başer, K.H.C. (2000). Flora of Turkey and the East Aegean Islands. Vol: 11. Edinburg: Edinburg Univ. Press, Edinburgh.

İbret, B. Ü. (2003). Tarihi İpek Yolu Üzerindeki Bir Anadolu Şehri: Tosya (Kuruluşu ve Gelişmesi). Marmara Coğrafya Dergisi, 8.

İbret, B. Ü. (2013). Tosya Şehrinin Fonksiyonel Özellikleri. Marmara Coğrafya Dergisi, 9, 49-88. (http://earsiv. kastamonu.edu.tr/jspui/handle/1/324)

T.C. Tosya Kaymakamlığı Brifingi, (2013). www.tosya.gov.tr, Erişim Tarihi: 06.01.2014.

Tosya Belediyesi web sitesi. (2017). tosya.bel.tr, erişim tarihi 20.06.2017.

Tuttu, G.. (2017). Flora and Ethnobotany of Tosya District (Kastamonu), Unpublished PhD thesis, Çankırı Karatekin University, Çankırı.

Yıldırımlı, Ş. (2004). Etnobotanik ve Türk Etnobotaniği. Kebikeç, 17, 175-193. 